\author{
Elisabeth K. Kraus, Lenore Sauer \& Laura Wenzel
}

\title{
Together or apart? Spousal migration and reunification practices of recent refugees to Germany
}

\begin{abstract}
:
This study examines migration and reunification processes among recent male and female refugees from Afghanistan, Iraq, and Syria in Germany. Specifically, we analyse different types of spousal migration practices (joint arrival versus arriving alone) and the probability of reunification with the left-behind partner after one year of geographic separation, and to what extent this is shaped by socio-economic conditions, children, family networks, and the legal situation of married men and women. Using data from the first and second wave of the IAB-BAMF-SOEP Survey of Refugees, collected in 2016 and 2017 in Germany, and applying logistic regression models, we disentangle the heterogeneity of refugees' migration processes. The results show that couples with minor children are more likely to migrate together compared to childless couples or those with adult children only, and that men and women's solo migration is associated with the presence of other family members at the destination country. The probability of reunifying with the left-behind partner after one year of separation mainly depends, again, on family networks, with differential effects for men and women. Furthermore, male first-movers' legal status in Germany is important for a quick reunification with their wives. Our research shows that forced migration in the here studied geographic context is a gendered process and that several characteristics of male migration do not apply to women. Furthermore, conventional explanations for economically motivated migration decisions and patterns must be adapted to the case of forced migration.
\end{abstract}

Key words: family reunification, couple migration, forced migration, refugees, Germany

\section{Introduction}

The number of forcibly displaced people worldwide reached its peak in 2018 with approx. 70.8 million persons, 29.4 million of whom are either international refugees or asylum seekers (UNHCR 2019). The great majority flees to neighbouring countries. Nonetheless, the on-going conflicts in Afghanistan, Iraq, Syria and other countries have also contributed to sharply rising numbers of people arriving in high-income countries elsewhere to claim asylum. Germany is one of the major destination countries with more than 740,000 men and women submitting their initial asylum application in 2016 (BAMF 2018). Per- 
mits for family reasons have increased sharply worldwide (UNHCR 2019), but also in Germany (BMI/BAMF 2019).

Quantitative studies on refugee ${ }^{1}$ populations in European destination countries are scarce, even more so when it comes to their family arrangements, family reunification processes, and differences between sexes. So far, studies examining refugees and their family structures focus on the life satisfaction of refugees in Germany (Gambaro et al. 2018), on the labour market and educational integration into the host society (Bürmann et al. 2018; Bähr et al. 2019; Brücker et al. 2019; OECD 2017) or on transnational activities with family members in origin or transit countries (Bakker et al. 2014). Further research deals with ICT communications and channels of contact of recently arrived refugees in Germany (Baldassar 2016; Witteborn 2015). Finally, the mental well-being, post-traumatic stress and psychological problems of refugees have been studied extensively (Schouler-Ocak/ Kurmeyer 2017). ${ }^{2}$

Research on partnership arrangements and gendered migration processes mainly focuses on economically motivated migration. Most of these quantitative studies deal with Mexican male and female migrants to the United States of America (Kanaiaupuni 2000; Cerrutti/Massey 2001; Curran/Rivero-Fuentes 2003; Cerrutti/Gaudio 2010), as one of the largest and best-established migratory systems, with the Mexican Migration Project providing valuable data on gendered migration practices. Focussing on Sub-Saharan African migration to Europe, several studies analyse family migration dynamics. Many of these publications are based on data collected within the framework of the Migrations Between Africa and Europe project (Beauchemin et al. 2015; Caarls/Mazzucato 2015, 2016; Caarls/Valk 2017; Caarls et al. 2018; Toma/Vause 2013; Kraus 2019). There are also some noteworthy qualitative studies examining female migration from Sub-Saharan Africa (Vives/Vazquez Silva 2017), gendered family migration processes in Southeast Asia (Fresnoza-Flot 2018; Parreñas 2005), as well as family migration in the regional context of Mexico and Central America (Dreby 2010; Schmalzbauer 2010; Baldassar/Merla 2014). Moreover, several studies examine partnership-related migration dynamics for the case of the 1950s-1970s Gastarbeiter ('guest workers') from Southern Europe and Turkey and subsequent generations, mostly in Germany, the Netherlands, and Belgium (González-Ferrer 2007; Guveli et al. 2016). Yet it remains unclear if and to what extent labour migrants' family arrangements and spousal migration practices show similar patterns compared to those of refugees.

This study brings the literature on refugees into conversation with the literature on family and spousal migration processes by addressing the following three research questions: What are the characteristics of international refugees' spousal migration practices regarding type, pace, and eventual reunification at destination? How are socio-economic status, children, family networks, and legal aspects related to these differential arrangements? And finally, what are the differences in the migration processes of male and female refugees? An-

1 Throughout the article we use the terms 'asylum seeker', 'refugee' and '(forced) migrant' interchangeably, all three referring to persons who arrived at a specific country of destination, and filed an asylum application. Thus, we do not account for the outcome of their asylum procedure, nor their current legal status.

2 For an overview of the state of the art of research on family life in the context of forced migration see Sauer et al. 2018. 
swering these questions enables us to compare refugees to previous findings on other types of migrants and to disentangle potential diverging patterns between these groups.

Previous research has discussed whether different forms or categories of migration should be considered at all (Long 2013; Richmond 1993; Zetter 2007, 2015). On the one hand, motives and causes for different forms of migration overlap. Therefore, the dichotomisation between external coercion and internal voluntariness as well as a clear distinction between political and economic motives for migration is difficult (Castles 2007; Collyer/Haas 2012; Crawley/Skleparis 2018; Koser/Martin 2011). On the other hand, refugee families show important differences to other migrant families. For most refugees, the possibility of migrating to a third country involves forced separation from the family and limited control over the events of the flight, so that their migration experiences differ significantly from migrant families who have consciously opted for separation (Robertson et al. 2016). Furthermore, different types of migrants are granted different rights to move across national borders and reside in other countries. The right of residence is also accompanied by rights such as access to the labour market or possibilities of family reunification (Morris 2002; Söhn 2013). Against the background of these two opposing views, one of the aims of our contribution is to examine refugees' migration dynamics, and to compare this specific group to existing literature, which focuses mainly on labour migrants.

The empirical analysis builds on the first two waves of a recent and hitherto unique dataset, the refugee sample of the German Socio-Economic Panel (IAB-BAMF-SOEP Survey of Refugees, carried out in 2016 and 2017). Containing questions not only on the current family situation and the whereabouts of both partners, but also on aspects of the person's migration history and the legal situation, it allows for quantitative analyses of family arrangements and spousal migration practices of refugee families. Our focus is on married men and women originating from Afghanistan, Iraq and Syria, currently the three major countries of origin of refugees in Germany.

The contributions of this study are twofold; first, we complement and enhance the existing literature on family migration and reunification by examining hypotheses about gendered family migration processes in other contexts and applying them to the case of forced migration. Second, our results show specific migratory and demographic patterns for refugees and their families in Germany. These results may help in opening up the black box of refugees' family reunion processes, providing valuable insights for other European destination countries with large refugee communities, such as France, Italy or Sweden.

\section{Forced migration from Afghanistan, Iraq and Syria and the situation of refugees in Germany}

Between 1990 and 2018, 4.8 million people applied for asylum in Germany (initial and subsequent applications). A preliminary peak with about 438,000 persons was reached in 1992 (BAMF 2019b). After that year, the number of applications began to decline, partly due to more restrictive asylum policies and procedures, as well as the end of the civil war in former Yugoslavia, reaching its lowest level with approx. 20,000 applications annually between 2006 and 2008. Since then, the numbers of asylum seekers in Germany steadily 
increased once again (as illustrated in Figure 1): In 2014, slightly more than 202,000 people lodged an initial asylum application, in 2015 the number more than doubled to nearly 442,000 , further rising to 722,000 in 2016 (BAMF 2019b). Due to rising institutional barriers in transit countries, as well as the closure of the 'Balkan route' and the EU-Turkey agreement in March 2016, the number of new asylum seekers arriving in Germany has since fallen sharply. In 2017 and 2018, less than 200,000 asylum applications were filed (BMI/BAMF 2019; BAMF 2019b).

Figure 1: First-time asylum applications in Germany by sex and country of origin, 2010-2018
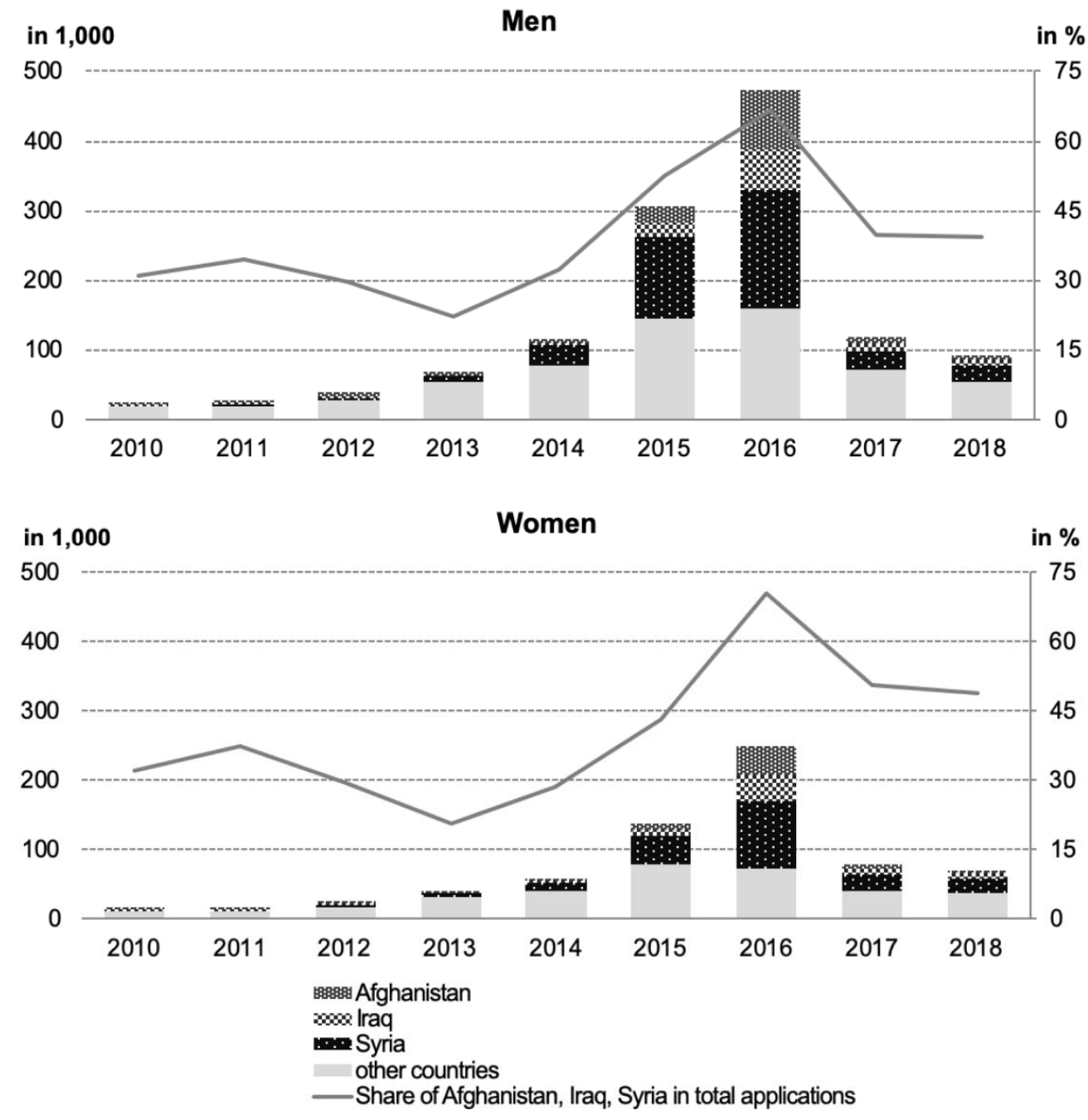

Data: BAMF (different years): Das Bundesamt in Zahlen. Nürnberg: BAMF. 
Most of these refugees fled from the crisis regions of Syria, Afghanistan, and Iraq (BAMF 2019b). Excepting 2013, between 2010 and 2018 more than one-third of first-time asylum applications were filed by people from these three countries (see Figure 1). The proportion of people holding these three citizenships as a share of total applications has rapidly increased, accounting for 50 per cent in 2015, 68 per cent in 2016, and 44 per cent in 2017 and in 2018 (BAMF 2019a). Whereas the number of rejections of asylum applications was very low for Syrians (2018: less than 1 per cent), it was much higher for Afghans and Iraqis (2018: 50 and 54 per cent, respectively; BAMF 2019b). The official data on asylum seekers in Germany reflect a male-dominated sex ratio for Afghan and Syrian asylum seekers (about two-thirds were male), whereas it is relatively balanced for Iraqis (50 to 60 per cent male). While this proportion is rather robust for Afghanistan, it slightly changes for Syria. From 2010 to 2013, about 60 per cent of the first asylum applications by Syrians were lodged by men, in 2014 and 2015 the proportion increased to 71 and 74 per cent, respectively, and dropped in 2016 (64\%), 2017 and 2018 (52\%).

By focusing on asylum seekers from Syria, Afghanistan, and Iraq, this article concentrates on refugees from three countries which have suffered from civil war, instability, severe insecurity, and violent conflicts. Broadly speaking, Syrians fled mainly from civil war and its direct and indirect effects, Afghans mostly fled from Taliban rule, and Iraqis escaped from the ISIS and the 'War on Terror' (Hessels/Wassie 2003). The main difference between the three countries may be the temporal dimension of the flight movements: Contrary to Syrian flight migration in a few short years peaking in 2015, migration has been a fundamental coping and survival strategy throughout the history of Afghanistan and increasingly over the past four decades (van Houte 2016), and has a longer history for Iraq as well. Furthermore, flight patterns and routes as well as the duration of time between departure from the country of origin and arrival in Europe and Germany vary across the three countries (Brücker et al. 2016; Crawley et al. 2016).

The context of reception shaped by destination governments has a major impact on legal family reunification processes, providing different options for specific groups of asylum seekers: For Germany, this context is shaped mainly by the constitutional right to asylum, refugee protection pursuant to the Geneva Convention on Refugees, subsidiary protection, and a tolerated status called 'temporary suspension of deportation' (BMI/ BAMF 2019). Each protection status is associated with different legal rights, including family reunification. Only persons who have received asylum in accordance with the German constitution or the Geneva Convention have an unrestricted legal right to family reunification. The right to family reunification applies to the nuclear family, i.e. for adult applicants, this refers to their spouse or registered partner as well as unmarried children aged under 18 years. In the case of minor applicants, this refers mostly to their parents (Grote 2017). In March 2016, for refugees with subsidiary protection status, family reunion was halted, but partially resumed in August 2018. For persons with a temporary suspension of deportation, family reunification is not possible. 


\section{Theoretical framework and hypotheses}

Family and couple migration decisions, trajectories, and outcomes may take a variety of diverse forms and patterns, involving different actors at the household or family level making a typology of these arrangements challenging. For economically motivated migration from Mexico to the United States of America, Hondagneu-Sotelo (1994) developed a typology distinguishing between three main forms of migration: 1) independent, which captures single men or women who migrate alone; 2) family unit, corresponding to families who migrate together; and 3) family stage, which captures families in which one spouse typically the husband - migrates first and the other spouse and children may follow in a subsequent stage.

Traditionally, in family stage migration processes women are considered as "secondary" or "associational" migrants (Kanaiaupuni 2000; Cerrutti/Massey 2001) who do not actively take part in household decision making, but who are rather left behind at the place of origin (Cerrutti/Massey 2001: 188). In some cases, they may follow their husband for matters of family reunification rather than for being economically active themselves (Kanaiaupuni 2000). Female independent migration is still rather scarce from many countries of origin (Toma/Vause 2013). However, migration flows in other geographic contexts are, in fact, highly feminised as it was the case for Latin American migration to Spain in the early 2000s (Bueno García/Vono de Vilhena 2009), or the circular migrations of female workers in the service sector from Eastern to Western and Central Europe (Lutz 2004).

In the context of forced migration, however, it may be more likely that refugees attempt to enter the destination country with the entire family (Kofman 2004), because leaving the partner and children behind in a dangerous area of conflict may not be regarded as an option. Yet family stage migration processes of refugees often occur involuntarily or as a temporary strategy (Jastram/Newland 2003; Sample 2007). In that case, members of an extended family may pool their resources to send their most capable members away, in order to find a place from where to send money home to support the others. Another approach may be to send the most vulnerable, often children, away (e.g. in the case of forced recruitment). But, in most cases, family reunification is the first priority for refugees upon receiving status (for an overview see UNHCR 2013). Furthermore, refugees in high-income countries are more likely to be male, and as a consequence a large number of women-headed households may be found in refugee camps in lower-income countries (Martin 2009). Another explanation for the unequal distribution of male and female refugees across countries may be based on the difficulties of entering destination countries through legal channels, and men are expected to endure suffering and hardships during the journey and the illegal situation at destination more easily than women are.

In the remainder of this section, we discuss different theoretical approaches that deal with the major drivers of family migration and reunification processes in the context of international migration, and whether they are relevant to understanding refugee couples' migration dynamics. With this in mind, we derive our hypotheses. Besides financial resources also the existence and number of children, family networks and family support, as well as legal conditions at destination are factors that have been identified to be related to spousal migration and reunification practices. 


\section{Financial resources}

Socio-economic status has been found to be crucial for family migration and reunification processes in the context of economically motivated migration. The economic situation of a couple is likely to influence the decision of whether to migrate together, or to have one partner migrate first and "once he or she settled in the host country and enough economic returns have been made to pay for the arrival of other family members" (Haagsman 2015: 27). In the context of forced migration, van Hear (2014: 100) argues that "the form of migration and ultimately its outcomes are shaped by the resources that would-be migrants can muster and that in turn the capacity to mobilize such resources is largely determined by socio-economic background or class". It can be assumed that refugees applying for asylum in Germany were financially better-off before leaving their country of origin than those who are still at origin or in neighbouring countries, since reaching more distant countries usually implies higher costs (Jastram/Newland 2003; González-Ferrer et al. 2014). Also, for couples who are financially better off, it might be easier to travel directly to the planned country of destination with the entire family (e.g. by plane), compared to economically poorer families, who might leave the country of origin together, but due to scarce financial resources may be forced to leave one partner behind in a transit country (Jastram/Newland 2003), reducing the chances of arriving together at destination. In most contexts, it is the husband who leaves his wife and children in the country of origin or of first asylum to make the journey alone (Jastram/Newland 2003). In our first working hypothesis we anticipate:

Hla: Couples with higher financial resources in their country of origin are more likely to migrate and arrive at destination jointly than couples who are economically worse off.

The financial status of a couple should also be important for the reunification at destination. In most cases, family reunification with their left-behind family members is the first priority for refugees upon their arrival at destination. Although reunification via the legal channel is not linked to economic prerequisites, financial resources should help reunification through other channels. Our hypothesis is:

H1b: For couples with high financial resources, reunification with the partner at destination should occur faster than for couples who are economically worse off.

\section{Existence and number of children}

Previous research on labour migrants found a positive relationship between the number of children and the probability of male out-migration (Massey/Espinosa 1997), while mothers of young children in particular have relatively low propensities of migrating or joining their partner in travelling to destination (Kanaiaupuni 2000). Furthermore, children are an important factor influencing the decision of joint versus independent migration and the pace of the reunification processes (Caarls 2015). It is likely that refugee couples with minor children intend to migrate jointly, because leaving the partner with dependent minors back at origin or in a transit country may imply major risks for the family. Literature on labour migrants has found a negative relationship between joint couple migration and 
the number of non-adult children in the household (González-Ferrer 2007). This is also expected to be true for forced migrants, since moving with a larger number of persons is more challenging in terms of financial and organizational resources. Moreover, for labour migrants, the age of minor children is crucial. Literature distinguishes between school-age and younger children. Once at destination, children aged six and above can attend school and hence do not represent an obstacle for parents' work and saving capacities (GonzálezFerrer 2007). However, the integration into the destination labour market of refugees is very slow, especially for women, as has been shown in recent studies (Brücker et al. 2019). Hence, the age of minor children may not matter as much for refugees, but their number should be important. We hypothesise the following:

H2a: Joint couple migration is more likely among couples with minor children, compared to childless couples or those with adult children only. The number of minor children, however, should be negatively related to joint couple migration.

For labour migration, Caarls (2015) found that having children reduced the likelihood of reunification at destination and González-Ferrer (2007) showed that the number of children a couple has did not impact the pace of reunification with the left-behind wife. We hypothesize that this might be different for forced migrants. Following the same rationale as in the previous paragraph, reunification with the left-behind partner should be quicker if couples have minor children; however, having a higher number of them should delay the reunification process (Di Barbiano Belgiojoso/Terzera 2018). We anticipate the following:

H2b: For couples that did not arrive jointly at destination, reunification should occur faster if they have minor children, compared to childless couples or couples with adult children only. The number of minor children, however, should be negatively related to the pace of reunification.

\section{Family networks and family support}

Migrant networks have been found to be one of the most important predictors for the initial decision to migrate as well as migration propensities (Massey 1990; Massey et al. 1987; Palloni et al. 2001; Winters et al. 2001). They can provide practical, emotional and informational support (Ryan et al. 2009). Particularly, the presence of the extended family, especially parents, is important (Staver 2008). Forced migration is fraught with uncertainties and the existence of migration networks at the potential country of destination may reduce these uncertainties (Koser/Pinkerton 2002; Barthel/Neumayer 2015). First, relatives that have arrived earlier at destination may have set positive examples showing that migration is feasible. Second, previously arrived refugees may provide social capital and destination-specific knowledge, e.g. on visas processes or travel routes (Neumayer 2005). Family networks not only have the function of providing information but they can also provide financial support. Studies on marriage migrants and labour migrants show that family reunification can take place despite the couple's difficult economic situation with the support of social and family networks (Di Barbiano Belgiojoso/Terzera 2018; Fresnoza-Flot 2018).

Until the late 1990s, it was assumed that migrant networks facilitate migration in the same way for both sexes. However, more recent research shows that networks have dif- 
ferent effects on female and male migration (Pessar 1999). Generally, female migration is seen as "more risky" than male migration (Heering et al. 2004). As a consequence, women benefit more than men from the presence of network members other than partners at destination as it is especially important to diminish these risks and uncertainties (To$\mathrm{ma} /$ Vause 2013; Winters et al. 2001). Women's networks often consist of close family members who can be trusted to protect and look after women and "provide reliable information and the necessary support" (Toma/Vause 2014: 976). Hence, as the risks involved in forced migration processes are considerably higher, we assume that family networks are even more important for refugees and in particular for women. Thus, with regard to family networks, we formulate the following:

H3a: The availability of family networks at destination is crucial for the solo migration of one partner compared to joint couple migration. The presence of extended family members at destination should be particularly relevant for female-initiated compared to maleinitiated spousal migration processes.

Furthermore, the time until reunification at destination of separated couples should be linked to the presence of other family members at destination. Family members at destination may provide necessary resources and destination-specific knowledge, which can facilitate and accelerate processes of family reunification (Barthel/Neumayer 2015). We hypothesize:

H3b: The availability of family networks at destination should facilitate a faster reunification with the left-behind partner.

\section{Legal status}

For economic migrants, the pioneer spouse applies for legal family reunification as soon as they are legally allowed to do so, following the legal family reunification programmes of destination countries (Fresnoza-Flot 2018). In the context of forced migration, individuals who have to leave behind their family, once they reach safety, the reunification with their spouse and children is in most cases the key priority (Wilmsen 2011). In general, the legal framework of the destination country influences not only which immigration possibilities family members have, but also which normative family model is promoted and who is included in the family concept (Geisen 2014). There is an increasing gap between the pluralisation of normative family models of Western societies and the prevailing migration policy, which structurally follows the norm of the nuclear family and does not recognize other culture-specific family relationships (Staver 2008; Kofman et al. 2011). Furthermore, strict policies and legal conditions may slow down or even prevent family reunification (Glick 2010). We anticipate that:

H4: A secure legal status of the first-mover, which allows legal family reunification, should enable a faster reunification with the partner at destination. 


\section{Data and methods}

\section{Data: IAB-BAMF-SOEP Survey of Refugees}

The empirical analyses draw on data collected as part of the German Socio-Economic Pan$e l$, addressing people who seek asylum in Germany. ${ }^{3}$ The first wave of the $I A B-B A M F$ SOEP Survey of Refugees was carried out in Germany in 2016, the second wave in 2017. The sample was drawn from the German Central Register of Foreigners (Ausländerzentralregister), which covers all non-German nationals who have settled in Germany for longer than three months. The sampling was based on a stratified multi-stage clustered sampling design (Kroh et al. 2018). In the first stage, 170 sample regions across Germany were selected. In the second stage, a random sample was drawn from the addresses provided by the immigration offices within each sample region. Different sampling probabilities according to an individual's country of origin, current legal status, age, as well as sex were assigned. The sampling frame covered all adult individuals (aged 18 or older) who arrived in Germany between 2013 and 2016 and who have filed an asylum application at the Federal Office for Migration and Refugees (BAMF) or were hosted as part of specific programmes of the federal government or of a federal state (Bundesland), regardless of the outcome of their asylum procedure and their current legal status. The dataset contains representative data on persons who applied for asylum in Germany between 2013 and 2016, including individuals whose asylum procedure was still on-going at time of the data collection, were granted asylum, or with a ban on deportation.

Since the survey was implemented as a household survey, the sampled persons - the so-called 'anchor respondents' - as well as all other adult individuals cohabiting in the same household were interviewed. The questionnaire was available in seven languages (German, English, Arabic, Farsi, Kurmanji, Pashto, Urdu). The overall response rate was about 50 per cent (Kroh et al. 2018). In total, 7,430 face-to-face individual interviews thus persons who participated in at least one of the two waves - in 4,994 households were conducted. 26 per cent of the respondents participated in both waves (Brenzel et al. 2019). Design weighting procedures allow for representative analysis on both the household and the individual level. ${ }^{4}$

\section{Analytical sample}

The initial sample of interviewed refugees comprises men and women from various countries of origin (Afghanistan, Albania, Eritrea, Iran, Iraq, Kosovo, Pakistan, Serbia, Somalia and Syria, among others). We restrict our analyses to individuals who were born in Afghan-

3 The IAB-BAMF-SOEP Survey of Refugees is a joint project of the Institute for Employment Research (IAB), the Socio-Economic Panel (SOEP) at the German Institute for Economic Research, and the Research Centre on Migration, Integration, and Asylum of the Federal Office for Migration and Refugees (BAMF-FZ). It is designed as an annually repeated panel study of refugee households that will prospectively be implemented into the German Socio-Economic Panel.

4 For more detailed information on the IAB-BAMF-SOEP dataset refer to Jacobsen et al. 2017; Kroh et al. 2016; Kroh et al. 2018; Brenzel et al. 2019. 
istan, Iraq or Syria. Refugees from other origins were excluded, since their sample sizes were relatively small and no valid conclusions regarding the effect of the country of origin could be drawn. Afghanistan, Iraq and Syria are the largest groups in the IAB-BAMF-SOEP data. They also represent the most common countries of origin of refugees arriving in Germany in recent years (see Figure 1). In total, the survey includes data on 5,647 adult individuals born in Afghanistan, Iraq or Syria, and holding the citizenship of the respective country, drawn from the sampled anchor respondents and their spouses (in case they were also interviewed). Hence, other respondents living within the same household, such as adult children, parents, or siblings were dropped from the sample. Anchors that were single (including divorced and widowed) at the time they were first interviewed or had an unmarried partnership were also excluded, as well as those with unknown marital status. We also had to drop observations of anchors and/or partners with missing data regarding the spouse's place of residence. Somewhat more than two-thirds of the cohabiting partners participated in an interview; for cohabiting spouses that were not interviewed and those residing elsewhere in Germany, we do not know their exact date of arrival in Germany and thus cannot compute whether they arrived together or prior/after the anchor person. However, respondents who were interviewed in both waves were asked who - the respondent themselves or their partner - arrived in Germany first. For the sake of increasing the size of our sample, we used this information to derive their date of arrival. Finally, persons who arrived in Germany before 2013, before age 17 or after age 50, or with missing information on age or sex were also deleted. The remaining sample covers 2,107 opposite-sex couples. As we are interested in information upon arrival, a cross-sectional dataset was constructed with one observation per respondent, although for some of the respondents we have two measurement points (corresponding to waves 1 and 2).

\section{Dependent variables and method}

The empirical part of this analysis consists of two steps; in the first step, we analyse whether spouses arrived together in Germany or whether one of them arrived first and the other stayed behind. Hence, our dependent variable is binary with two possible outcomes: 1 if the spouses arrive in Germany together and 0 if one of them arrives earlier, leaving the other behind ${ }^{5}$. As the outcome variable is dichotomous, logistic regression models are estimated. Based on current research, we expect different dynamics underlying male- and female-initiated migration processes. Therefore, the statistical analyses are carried out in separate models for men and women, examining how the covariates have different effects for married women who arrived together with their husband compared to married women who migrated alone, and vice versa for men. The models for women include 836 individuals who migrated together with their husband and 146 who arrived first $(\mathrm{N}=982)$. The models for men contain 894 observations of joint and 436 of male-initiated migration $(\mathrm{N}=1,330)$.

5 If the difference between both partners' arrival in Germany was one month, they were considered as 'joint migrants'. The analyses were also performed classifying couples with 2 or 3 months of difference between their arrivals at destination as 'joint migrants' with no substantial differences in the obtained results. 
In the second step, we examine only those couples who did not arrive at destination together. Therefore, all couples who arrived in Germany together were dropped from the analysis sample. Moreover, couples for whom we do not know the exact date of arrival for at least one of the partners - and thus cannot compute the duration of stay at destination -, or the duration of stay was less than 12 months at survey were dropped. Again, a binary dependent variable was constructed, taking the value of 1 if the couple has reunified in Germany after having been separated for 12 months or less, and 0 if the couple was still separated at the time of the interview or the duration of separation took more than 12 months. The sample sizes for this second step are 32 women whose husband already had arrived at destination versus 77 who were still separated or whose partner arrived after more than one year $(\mathrm{N}=109)$. For males, 122 were reunified with their partner versus 219 who were still separated after 12 months $(\mathrm{N}=341)$. Again, logistic regression is used.

\section{Independent variables}

Due to the rather small sample sizes, especially for women in the second step, only a limited number of explanatory variables could be included in the multivariate analyses. Some variables are used for both steps of the analyses, others only in the first or the second, depending on the hypotheses being tested. We present the descriptive statistics for the first step only, as displayed in Table 1 (Table A1 in the appendix shows the descriptive statistics for step 2). All variables are measured at the level of the first-mover or the corresponding sex in case they migrated together.

Our hypotheses focus on the financial situation, family networks and family support, as well as the existence and number of children as explanations for spousal migration practices. The financial situation is operationalized by 1) relative subjective net income before flight and 2) direct or indirect migration to Germany. The respondents were asked to remember the time before the war, crisis or conflict in their respective country of origin and to compare their net income at that time with the income of other people in their home country. This variable has four categories: "above average", "average", "below average", and "not/never worked". The latter category includes men and especially women who did not work at the time (or never did), and therefore did not obtain any income. Not surprisingly, this variable shows important differences by sex: about 68 per cent of women and only 4 per cent of men indicated that they did not work ${ }^{6}$. Among women, 12 per cent had an average or below average net income, respectively, while 6 per cent had an income above the average, whereas among men 27 per cent had a net income below average, 42 per cent average, and 22 per cent above average. To proxy the financial situation in the country of origin, we added a dummy variable measuring whether Germany was the first country they moved to ("directly to Germany") or whether they lived in another country for at least three months ("indirectly via another country"). We assume that those who could afford a direct journey to Germany were financially better off. Approximately two thirds of the women and men indicated that they took a direct travel route to Germany ${ }^{7}$.

6 All percentages are weighted.

7 It is possible that the respondents did not answer truthful to this question, as they might fear that a transit stay in any other EU country before arriving in Germany might have negative consequences 
Table 1: Descriptive statistics of independent variables by sex; joint arrival versus arriving alone (step 1)

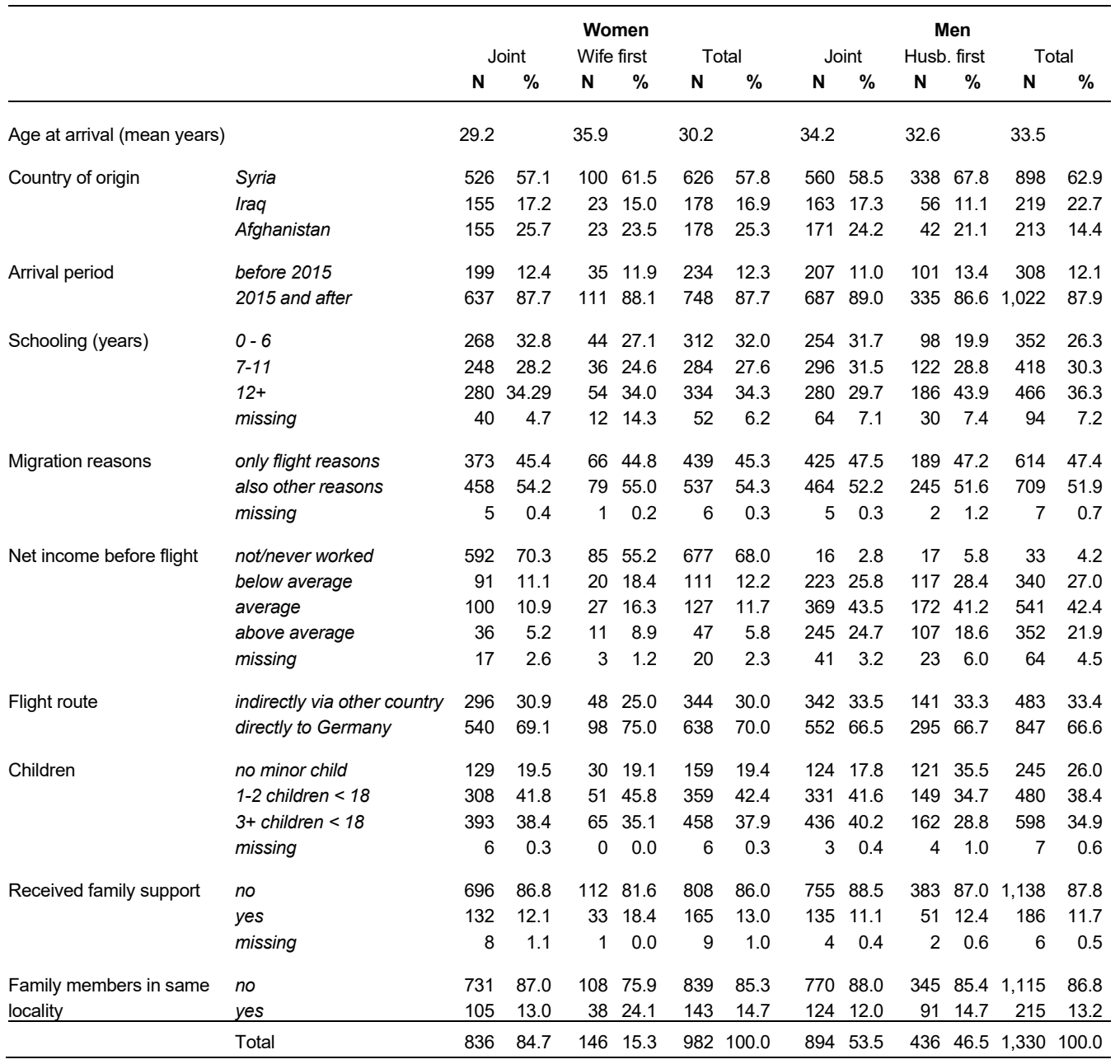

Data: IAB-BAMF-SOEP, wave $1 \&$ 2, 2016-2017 (unweighted N, weighted percentages); due to rounding percentages may not total $100 \%$.

To test our hypotheses on the effect of existence and number children on the type and pace of spouses' migration, a categorical variable distinguishing between "no minor child", which includes childless couples as well as couples with children aged 18 and older only, "1-2" and " $3+$ " children, was used. Children born in Germany after arrival of the

for their on-going asylum application due to the EU Dublin Regulation. However, these potential inaccuracies are not expected to be different for individuals arriving with their partner compared to those arriving alone, and thus should not make a major difference regarding the results. 
first-mover were excluded. Nearly one in five women and one in four men is childless or has adult children only.

Family networks were operationalized by 1) family support and 2) the presence of other family members in the same locality/region in Germany. The respondents were asked whether any relatives already residing in Germany supported them at the time they arrived. We constructed this variable as a dummy, distinguishing between individuals who received support from their family and those who did not. The large majority did not receive this kind of support ( 86 per cent of women, 88 per cent of men). Furthermore, the dataset contains a number of questions concerning the place of residence of different family members (spouse, children, siblings, parents, and other close relatives). We use a dummy variable indicating whether the respondent had at least one of these family members in the same locality in Germany or in the same household versus not having any family members nearby. Only about 15 and 13 per cent of the women and men, respectively, had family members living either in the same household or in the same locality. Unfortunately, it remains unclear since when these other family members resided in Germany and whether they arrived together with, before or after the respondent. Cross-tabulating this variable with the variable on received family support shows that individuals with family members present in the same locality are the ones who receive less family support and vice versa. This might indicate that many of the family members living nearby actually did arrive together with the respondent, while those who give support are the ones already residing in Germany.

Furthermore, several independent variables controlling for basic demographic and migration-related aspects were included in the models (see Table 1). Age at arrival is a continuous variable ranging from 17 to 50 with a mean age of 30 for women and 33 years for men. For the period of arrival, we used two categories ("before 2015" and " 2015 and after"). The variable country of origin distinguishes between Syria, Afghanistan and Iraq. Furthermore, a measure for years of schooling - collapsed into the categories " $0-6$ " "711 " and " $12+$ years" - was included. 32 per cent of women and 26 per cent of men attended school for only six years or less (including not at all), while 34 per cent of the women and 36 per cent of the men attended school for 12 years and more. This means that more than one-third completed secondary education, which confirms the educational selectivity of refugees from these three origins arriving in Germany, especially for highly educated women. The respondents were also asked for the main reasons for leaving their country of origin by selecting several responses. Based on this, we constructed a dummy variable aiming at capturing different motives for leaving the country of origin and distinguishing between respondents who imply fled ("only flight reasons"), and those who also gave other reasons ("reasons beyond flight"). ${ }^{8}$ Somewhat more than half of the male and female respondents also indicated reasons beyond flight as motives for leaving their country of origin. Finally, as the survey consists of three different survey samples (called M3, M4, M5), a control variable distinguishing between them was added.

8 "Flight reasons": fear of violent conflict or war, fear of forced conscription into military or armed organizations, persecution, ethnic/religious/etc. discrimination; "reasons beyond flight": poor personal living conditions, country's general economic situation, move to where my family members were, my family sent me, because family members had left this country, because friends/acquaintances had left country, other reasons. 
In the second step, a reduced number of covariates was included, since not all measures are associated with the reunification of the left-behind partner and, technically speaking, sample sizes in this second step are even smaller (see Table A1 in the appendix). Of the key independent variables, only the measures for net income, children, and the presence of family members were incorporated into the models. The control variables were the same, save for the measure for country of origin, as very few women from Afghanistan and Iraq remained in the reduced sample. Furthermore, we assume that reunification with the partner is associated with the current legal status of the first-mover. Therefore, we aggregated the information on the residence title into two categories. The first one represents all permits that allow a more or less secure residence and the legal reunification with the spouse (and children) and covers the following status groups: entitlement to asylum according to the German constitution, refugee protection pursuant to the Geneva Convention on Refugees, or subsidiary protection ${ }^{9}$. About 64 per cent of women and 59 per cent of men hold one of these titles. The second category comprises all other - rather insecure - residence titles.

\section{Results}

Figure 2 shows that flight from the three origins to Germany is male-dominated: Slightly more than half of all couples arrived together, for more than 40 per cent of all couples the man arrived first, and for only 8 per cent the woman was the first-mover. The graph also shows that within 12 months after arrival, 18 per cent of the husbands and almost 27 per cent of the wives were reunified with their left-behind partners at destination. This indicates that also in the context of forced migration it is rather uncommon that married women arrive at the destination country before their spouses, and if they do so, their partner follows them relatively quickly. ${ }^{10}$

9 The majority of respondents arrived before the suspension of legal family reunification in March 2016.

10 The Kaplan-Meier survival estimates in Figure A1 in the appendix show a similar picture of couples in which the wife migrates first, which experience a faster reunification with their husband than couples for whom the man arrives first. 
Figure 2: Order of spousal migration and share of reunified couples

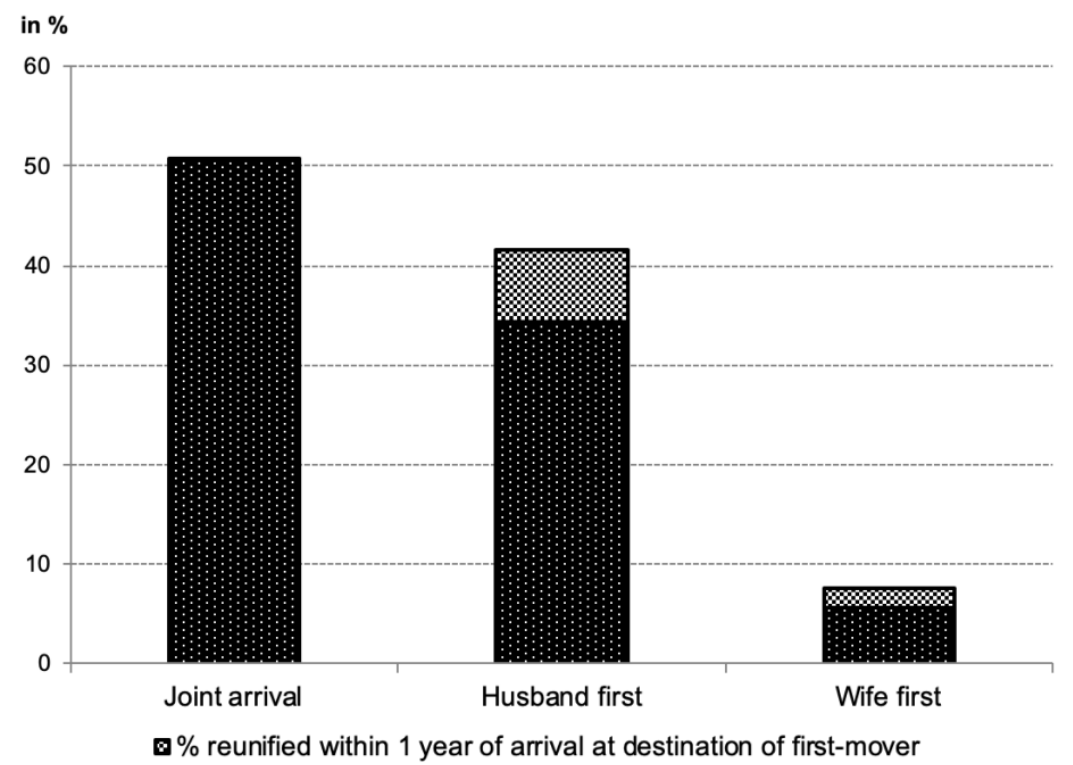

Data: IAB-BAMF-SOEP, waves $1 \&$ 2, 2016-2017 (weighted percentages).

\section{Joint arrival versus arriving alone}

In this first step, we analyse the determinants for joint couple migration compared to arriving alone, i.e. leaving behind the spouse (hypotheses 1a, 2a and 3a). Table 2 displays the results as odds ratios; covariates are included in a stepwise fashion. Models W1 to W2 present the odds ratios for women, while models M1 to M2 show those for men. In the models for women we compare married women who arrived together with their husband to married women who migrated alone, and vice versa for the models for men. Models W1 and M1 include the demographic and migration-related control variables, as well as the measures for financial status. The age of the respondent is significantly related to the type of spousal migration, but the effect goes in opposite directions for both sexes: while younger women are more likely to arrive together with their husband, among men the older ones are more likely to arrive together. Yet for men the significance disappears once adding the children's variable. The finding for women is opposite to the results of González-Ferrer (2007), who found a positive effect of the woman's age on joint migration for Turkish couples in Germany. However, she did find a negative relationship between years elapsed since marriage and joint migration, arguing that newly married couples are less prone to separate compared to couples who have been married for longer. Potentially, the negative age effect for female first movers in our models captures the negative effect of union duration, information that our data do not provide. Refugee men from Afghanistan and Iraq are more likely to arrive together with their wives compared to their counterparts from Syria, which could be related 
to the fact that crisis-driven migration from Iraq and, in particular, Afghanistan to Germany is older (i.e. well-established networks and communities exist), making joint migration relatively easier. Regarding educational attainment, the effects point into the same direction for both sexes, but only reach statistical significance for men: highly educated men with $12+$ years of education are more likely to migrate alone, leaving their wives behind. Apparently, the positive link between education and spousal migration that has been found for labour migrants in other contexts (Gupta 2003; Toma/Vause 2013) does not hold true for refugees, for which the underlying mechanisms might be different. The other control variables do not show any significant effects.

Table 2: $\quad$ Logistic regression models predicting joint arrival (versus arriving alone) by sex (step 1); odds ratios

\begin{tabular}{|c|c|c|c|c|c|}
\hline & & \multicolumn{2}{|c|}{ Women } & \multicolumn{2}{|c|}{ Men } \\
\hline & & W1 & W2 & M1 & M2 \\
\hline Age at arrival & & $\begin{array}{l}0.91^{* \star *} \\
(0.01)\end{array}$ & $\begin{array}{l}0.90^{* \star *} \\
(0.01)\end{array}$ & $\begin{array}{l}1.02^{* *} \\
(0.01)\end{array}$ & $\begin{array}{c}1.00 \\
(0.01)\end{array}$ \\
\hline $\begin{array}{l}\text { Country of origin } \\
\text { (Ref. Syria) }\end{array}$ & $\begin{array}{l}\text { Iraq } \\
\text { Afghanistan }\end{array}$ & $\begin{array}{c}1.36 \\
(0.38) \\
1.11 \\
(0.31)\end{array}$ & $\begin{array}{c}1.34 \\
(0.38) \\
0.97 \\
(0.28)\end{array}$ & $\begin{array}{l}1.94^{* * *} \\
(0.35) \\
2.45^{* * *} \\
(0.50)\end{array}$ & $\begin{array}{c}1.85^{\star \star \star *} \\
(0.34) \\
2.23^{*+* t} \\
(0.46)\end{array}$ \\
\hline $\begin{array}{l}\text { Arrival period } \\
\text { (Ref. before 2015) }\end{array}$ & 2015 and after & $\begin{array}{c}1.14 \\
(0.28)\end{array}$ & $\begin{array}{c}0.95 \\
(0.24)\end{array}$ & $\begin{array}{c}1.09 \\
(0.17)\end{array}$ & $\begin{array}{c}1.10 \\
(0.18)\end{array}$ \\
\hline $\begin{array}{l}\text { Schooling (years) } \\
\text { (Ref. 0-6) }\end{array}$ & $\begin{array}{l}7-11 \\
12+\end{array}$ & $\begin{array}{c}1.19 \\
(0.32) \\
0.97 \\
(0.26)\end{array}$ & $\begin{array}{c}1.30 \\
(0.36) \\
1.09 \\
(0.31)\end{array}$ & $\begin{array}{c}1.17 \\
(0.20) \\
0.71^{* *} \\
(0.12)\end{array}$ & $\begin{array}{c}1.22 \\
(0.21) \\
0.75^{*} \\
(0.13)\end{array}$ \\
\hline $\begin{array}{l}\text { Migration reasons } \\
\text { (Ref. only flight reasons) }\end{array}$ & other reasons & $\begin{array}{c}1.05 \\
(0.20)\end{array}$ & $\begin{array}{c}1.09 \\
(0.22)\end{array}$ & $\begin{array}{l}1.00 \\
(0.13)\end{array}$ & $\begin{array}{c}0.99 \\
(0.13)\end{array}$ \\
\hline $\begin{array}{l}\text { Net income bf. flight } \\
\text { (Ref. average) }\end{array}$ & $\begin{array}{l}\text { not/never worked } \\
\text { below-average } \\
\text { above average }\end{array}$ & $\begin{array}{c}1.41 \\
(0.40) \\
1.16 \\
(0.41) \\
0.97 \\
(0.42)\end{array}$ & $\begin{array}{c}1.48 \\
(0.42) \\
1.37 \\
(0.49) \\
0.97 \\
(0.43)\end{array}$ & $\begin{array}{c}0.60 \\
(0.24) \\
0.88 \\
(0.14) \\
1.09 \\
(0.17)\end{array}$ & $\begin{array}{c}0.66 \\
(0.27) \\
0.90 \\
(0.14) \\
1.12 \\
(0.18)\end{array}$ \\
\hline $\begin{array}{l}\text { Travel route } \\
\text { (Ref. Indirectly) }\end{array}$ & directly to Germany & $\begin{array}{c}0.89 \\
(0.18)\end{array}$ & $\begin{array}{c}0.95 \\
(0.20)\end{array}$ & $\begin{array}{l}0.69^{* * *} \\
(0.09)\end{array}$ & $\begin{array}{l}0.69^{* * *} \\
(0.09)\end{array}$ \\
\hline $\begin{array}{l}\text { Children } \\
\text { (Ref. no minor child) }\end{array}$ & $\begin{array}{l}1-2 \text { children }<18 \\
3+\text { children }<18\end{array}$ & & $\begin{array}{c}1.48 \\
(0.41) \\
1.75^{* *} \\
(0.48)\end{array}$ & & $\begin{array}{l}1.81^{* * *} \\
(0.31) \\
1.85^{* * *} \\
(0.34)\end{array}$ \\
\hline $\begin{array}{l}\text { Received family support } \\
\text { (Ref. no) }\end{array}$ & yes & & $\begin{array}{c}0.94 \\
(0.23)\end{array}$ & & $\begin{array}{c}1.30 \\
(0.25)\end{array}$ \\
\hline $\begin{array}{l}\text { Family members in same locality } \\
\text { (Ref. no) }\end{array}$ & yes & & $\begin{array}{l}0.32^{* \star *} \\
(0.08)\end{array}$ & & $\begin{array}{c}0.67^{* *} \\
(0.11)\end{array}$ \\
\hline & $\begin{array}{l}\mathrm{N} \\
\text { Pseudo } \mathrm{R}^{2}\end{array}$ & $\begin{array}{l}982 \\
0.10\end{array}$ & $\begin{array}{l}982 \\
0.13\end{array}$ & $\begin{array}{c}1,330 \\
0.08\end{array}$ & $\begin{array}{l}1,330 \\
0.10 \\
\end{array}$ \\
\hline
\end{tabular}

Data: IAB-BAMF-SOEP, waves $1 \& 2$, 2016-2017 (unweighted); standard errors in parentheses; controls for survey waves M3-M5; missing values in independent variables included as separate category, but odds ratios not displayed. ${ }^{*} p<0.1,{ }^{* *} p<0.05,{ }^{* * *} p<0.01$. 
Regarding the financial status, we hypothesized that higher financial resources at origin should be related to migrating and arriving together at destination (H1a). Looking at the results for women, it appears that those with lower financial resources (not/never worked and below-average income) are more likely to migrate together with their husband. Although statistically not significant, it might be an indication that these women are more dependent on their husband and his economic resources and thus these couples travel together. For men, the odds ratios correspond to the anticipated direction: while those who did not work or who had below-average income are less likely to migrate together, aboveaverage income is associated with joint arrival in Germany. However, these results also do not reach statistical significance. Furthermore, women and men who undertook a rather direct travel route to Germany are more likely to having arrived alone compared to those who had a prior stay in at least one other country of three months or longer, though significance is only reached in the models for men. Possibly, direct migration is a proxy not for higher financial resources, but rather an indication of a couple's migration strategy. The first-mover might take a direct route to Germany, which might be associated with higher costs, and thus wives and children stay behind. In sum, both measures for the financial situation of the first-mover fail to confirm adequately hypothesis H1a.

Models W2 and M2 added the variables for children and for family support and family members at destination. We hypothesised that joint migration is related to having minor children and their number $(\mathrm{H} 2 \mathrm{a})$. The results show that couples with minor children are more likely to arrive together compared to couples without minor children. The magnitude of the effect increases with the number of children. However, the difference between having 1 or 2 versus $3+$ minor children is statistically not significant. Thus, hypothesis $2 \mathrm{a}$ can be partially supported: while the existence of minor children favours a joint migration of couples, the number of them does not matter. ${ }^{11}$

Finally, with regard to family support and family members at destination, we anticipated that family networks are crucial for the solo migration of one partner compared to joint migration, in particular for women (H3a). Beginning with the availability of family members at destination, the odds ratios show that men and women with other family members in their household or locality are more likely to migrate alone, partly confirming our hypothesis. Family networks thus seem to be an important predictor for family stage migration processes in the context of forced migration. We assumed that the presence of extended family members at destination should be particularly relevant for female-initiated compared to male-initiated spousal migration processes. Apparently, in the context of forced migration, men also rely on family networks when they arrive at destination alone. It also has to be considered that possibly these other family members, in fact, arrived at destination together with or even after the respondent. Thus, no causal interpretation can be made, but the results may give us an indication that the role of the extended family is crucial for different migration strategies of couples. If the flight of the couple occurs within a broader context of family migration dynamics, solo migration of one of the partners seems to be a valid option. This is confirmed by additional analyses, in which we substi-

11 Complementary analyses showed that mother-child separations are rather uncommon among the refugee women in our sample, meaning that minor children in particular mostly stay and move together with their mothers. (Temporary) father-child separations, however, are slightly more frequent. 
tuted this variable with a broader measure, which covers family members residing anywhere in Germany (not only in the same locality). This other variable also shows a negative effect on joint couple migration; however, it does not reach statistical significance. This might be a further hint that the relatives residing in the same locality actually did arrive at destination together with the respondent. Interestingly, our second variable for family networks - having received support from relatives already living in Germany shows opposite effects for men and women, but is statistically not significant.

\section{Reunification at destination versus not (yet) reunified}

Table 3: Logistic regression models predicting reunification at destination within one year of arrival (versus not reunified) by sex (step 2); odds ratios

\begin{tabular}{|c|c|c|c|c|c|c|c|}
\hline & & \multicolumn{3}{|c|}{ Women } & \multicolumn{3}{|c|}{ Men } \\
\hline & & W3 & W4 & W5 & M3 & M4 & M5 \\
\hline \multicolumn{2}{|l|}{ Age at arrival } & $\begin{array}{c}0.97 \\
(0.03)\end{array}$ & $\begin{array}{l}0.94^{*} \\
(0.03)\end{array}$ & $\begin{array}{c}0.94^{*} \\
(0.03)\end{array}$ & $\begin{array}{l}1.01 \\
(0.02)\end{array}$ & $\begin{array}{l}1.01 \\
(0.02)\end{array}$ & $\begin{array}{l}1.00 \\
(0.02)\end{array}$ \\
\hline $\begin{array}{l}\text { Arrival period } \\
\text { (Ref. before 2015) }\end{array}$ & 2015 and after & $\begin{array}{l}0.60 \\
(0.36)\end{array}$ & $\begin{array}{c}0.51 \\
(0.33)\end{array}$ & $\begin{array}{c}0.56 \\
(0.36)\end{array}$ & $\begin{array}{c}0.85 \\
(0.25)\end{array}$ & $\begin{array}{l}0.86 \\
(0.26)\end{array}$ & $\begin{array}{c}0.80 \\
(0.24)\end{array}$ \\
\hline $\begin{array}{l}\text { Schooling (years) } \\
\text { (Ref. 0-6) }\end{array}$ & $\begin{array}{l}7-11 \\
12+\end{array}$ & $\begin{array}{c}2.56 \\
(1.57) \\
1.97 \\
(1.23)\end{array}$ & $\begin{array}{c}3.43^{*} \\
(2.32) \\
3.21^{\star} \\
(2.19)\end{array}$ & $\begin{array}{c}2.93 \\
(2.09) \\
3.00 \\
(2.06)\end{array}$ & $\begin{array}{c}0.50^{*} \\
(0.18) \\
0.72 \\
(0.22)\end{array}$ & $\begin{array}{c}0.48^{* *} \\
(0.17) \\
0.74 \\
(0.23)\end{array}$ & $\begin{array}{c}0.46^{* *} \\
(0.17) \\
0.67 \\
(0.22)\end{array}$ \\
\hline $\begin{array}{l}\text { Migration reasons } \\
\text { (Ref. only flight reasons) }\end{array}$ & other reasons & $\begin{array}{c}0.89 \\
(0.42)\end{array}$ & $\begin{array}{l}0.82 \\
(0.41)\end{array}$ & $\begin{array}{c}0.84 \\
(0.42)\end{array}$ & $\begin{array}{c}1.45 \\
(0.36)\end{array}$ & $\begin{array}{c}1.44 \\
(0.36)\end{array}$ & $\begin{array}{l}1.30 \\
(0.34)\end{array}$ \\
\hline $\begin{array}{l}\text { Net income bf. flight } \\
\text { (Ref. Men: average) } \\
\text { (Ref. Women: ever worked) }\end{array}$ & $\begin{array}{l}\text { not/never worked } \\
\text { below-average } \\
\text { above average }\end{array}$ & $\begin{array}{c}2.63^{*} \\
(1.41)\end{array}$ & $\begin{array}{l}3.21^{* *} \\
(1.91)\end{array}$ & $\begin{array}{c}3.06^{*} \\
(1.83)\end{array}$ & $\begin{array}{c}0.72 \\
(0.46) \\
0.79 \\
(0.23) \\
1.33 \\
(0.39)\end{array}$ & $\begin{array}{c}0.78 \\
(0.51) \\
0.72 \\
(0.22) \\
1.23 \\
(0.37)\end{array}$ & $\begin{array}{c}0.61 \\
(0.45) \\
0.70 \\
(0.22) \\
1.26 \\
(0.38)\end{array}$ \\
\hline $\begin{array}{l}\text { Children } \\
\text { (Ref. no minor child) }\end{array}$ & $\begin{array}{l}1-2 \text { children }<18 \\
3+\text { children }<18\end{array}$ & & $\begin{array}{c}0.65 \\
(0.55) \\
2.18 \\
(1.74)\end{array}$ & $\begin{array}{c}0.68 \\
(0.57) \\
2.26 \\
(1.86)\end{array}$ & & $\begin{array}{c}1.08 \\
(0.34) \\
1.57 \\
(0.56)\end{array}$ & $\begin{array}{c}1.09 \\
(0.36) \\
1.61 \\
(0.60)\end{array}$ \\
\hline \multicolumn{2}{|c|}{$\begin{array}{l}\text { Family members in same locality yes } \\
\text { (Ref. no) }\end{array}$} & & $\begin{array}{l}0.35 \\
(0.23)\end{array}$ & $\begin{array}{l}0.35 \\
(0.23)\end{array}$ & & $\begin{array}{l}1.86^{* *} \\
(0.55)\end{array}$ & $\begin{array}{l}1.74^{*} \\
(0.52)\end{array}$ \\
\hline \multirow[t]{2}{*}{$\begin{array}{l}\text { Legal status } \\
\text { (Ref. other status) }\end{array}$} & secure status & & & $\begin{array}{c}1.28 \\
(0.72) \\
\end{array}$ & & & $\begin{array}{c}3.07^{* \star * t} \\
(1.02) \\
\end{array}$ \\
\hline & $\begin{array}{l}\mathrm{N} \\
\text { Pseudo } \mathrm{R}^{2}\end{array}$ & $\begin{array}{l}109 \\
0.08\end{array}$ & $\begin{array}{l}109 \\
0.16\end{array}$ & $\begin{array}{l}109 \\
0.15\end{array}$ & $\begin{array}{l}341 \\
0.04\end{array}$ & $\begin{array}{l}341 \\
0.05\end{array}$ & $\begin{array}{l}341 \\
0.08\end{array}$ \\
\hline
\end{tabular}

Data: IAB-BAMF-SOEP, waves 1 \& 2, 2016-2017 (unweighted); standard errors in parentheses; controls for survey waves M3-M5; missing values in independent variables included as separate category, but odds ratios not displayed. ${ }^{*} p<0.1,{ }^{* *} p<0.05,{ }^{* * *} p<0.01$.

In the second step, we analyse the factors that determine whether or not couples reunified with their partner at destination within the first year after the first-mover's arrival (hy- 
potheses $1 b, 2 b, 3 b$ and 4 ). Table 3 presents the odds ratios for the logistic regression models predicting whether a reunification took place, accounting for nearly the same covariates as in the first step, which again are included in a stepwise manner (models W3 to W5 for women, models M3 to M5 for men).

Models W3 and M3 include demographic and migration-related characteristics, and the measures for financial status. For female first-movers, their age at arrival shows a significant and negative effect, indicating that older women, compared to their younger counterparts, are less likely to have reunified with their left-behind partners within one year. For women, we also find a strong effect of having $6+$ years of schooling, compared to having a lower level of education, while this is negative for men.

With regard to the financial situation at origin, we hypothesized that higher financial resources are associated with a faster reunification (H1b). For men, the odds ratios show the expected directions. Male first-movers reunified later if they did not work, or had a belowaverage net income in their country of origin. Men with an above-average income had higher odds of being together with their wives at destination within one year of arrival. However, none of these effects reaches statistical significance. Yet there is a slightly significant $(\mathrm{p}<0.12)$ effect of having had an above-average versus average income. For women, very small sample sizes within the different categories of the net income variable obliged us to use a slightly different measure, which only distinguishes between having never worked versus having worked already. There is a strong positive effect for women who have never worked. It is likely that these wives rely more heavily on their husbands' financial resources, and thus reunification occurs faster, which is in line with the findings that for women with less economic resources, joint migration with their husband is more probable.

In models W4 and M4 the measures for children and for the presence of other extended family members at destination are added. Hypothesis $2 b$ predicted a higher likelihood of reunification of couples with minor children. However, none of the effects is statistically significant. For women, when distinguishing between the number of children, there is a positive and significant effect $(\mathrm{p}<0.05)$ of having $3+$ children versus having only $1-2$ of them. Thus, hypothesis $2 \mathrm{~b}$ could be confirmed only in part; men join their wives faster at destination when the couple has a larger number of children.

Hypothesis $3 \mathrm{~b}$ predicted that family networks should accelerate the reunification with the left-behind partner. Surprisingly, the effect goes in opposite directions for men and women. While women who can count on other family members nearby reunify later with their partner $(\mathrm{p}<0.11)$, men with a local family network have a higher likelihood that their spouse will join them within one year of arrival. Accordingly, hypothesis $3 \mathrm{~b}$ can be confirmed for men only.

Finally, the last column (models W5 and M5) accounts for the legal status of the firstmover to test hypothesis 4 . The results should be viewed as exploratory and cautious interpretation is required, as there are several limitations in the way the variable for legal status was measured. There is a positive effect of having a secure status on the likelihood of reunification with the left-behind spouse, although it only reaches statistical significance for men. Though not surprising, it is remarkable that men with a secure legal status in Germany have a 3.07 times higher probability of reunification with their wives compared to those in a rather insecure situation. Thus, hypothesis 4 can be confirmed for men. One can assume that left-behind women join their husband via the legal channel of family reunification ('de ju- 
re'), while left-behind male partners rather try to come to Germany independently on the legal status of their wives, pursuing a 'de facto' reunification strategy.

\section{Discussion and conclusion}

Worldwide increasing numbers of residence permits for family reasons show that family migration processes are an increasingly important phenomenon, not only in the context of forced migration after wars and civil unrest, but also in other settings in which leaving behind close family members might not be a valid option (e.g. climate-driven migration). A shift from seeing migration as a purely economic strategy for income maximisation of the household or the family, usually based on circular migrations of only one family member, towards resettlement of entire family units can be observed globally. However, the extent and the determinants of bringing family members to the destination country, as well as the factors influencing the pace of spousal migration processes in the context of forced migration, remain largely unexplored so far. This is surprising, given the issue's salience and the large numbers of refugee families in European societies. Moreover, the family represents a "key source[s] of social and instrumental support for new migrants" (Glick 2010: 498) and the process of migration may change, reinforce or provoke conflicts in family ties (Glick 2010; Massey et al. 2006), and can affect refugees' well-being at the destination (Gambaro et al. 2018).

This paper has explored spousal migration processes of refugees in Germany, a country which has in recent years been characterised by relatively large inflows of asylum seekers from different countries of origin. The most common countries of origin were covered by this study - Afghanistan, Iraq, and Syria. In addition to providing descriptive findings, we have examined different types of spousal migration trajectories, the propensity of reunification of geographically separated couples within one year, and to what extent this is shaped by socio-economic conditions, the existence and number of minor children, family networks, as well as asylum status-related aspects for married men and women. The analyses point to several main conclusions: First, the great majority of couples from forced migration contexts arrive together at the destination country, or the husband arrives first with his wife staying behind in an origin or transit country. Only a small share of married women arrives without their partner at the destination country. The dominance of male pioneer migrants is in line with migration flows consisting of other groups of migrants (mainly labour migrants) and in other geographic settings. Second, the existence of minor children is crucial for a couple's joint arrival at destination. Parents of young children may feel additional pressure to keep the family unit together and jointly bring their offspring into safety. Third, our analyses did not arrive at statistically significant results regarding our expectations that economically better-off couples are more likely to come together to Germany and that - in case they migrate alone - reunification at destination occurs faster. Putting this into a broader context, it might be important to keep in mind that individuals from the three examined countries of origin, who actually make it to Germany represent a selected group of the respective origin populations, not only in terms of their sex and age distribution, but also in terms of their socio-economic profiles 
(which diverge from the national averages). Although research is scarce (for an exception see Stoewe 2018), it can be assumed that individuals who manage to undertake the long and oftentimes dangerous trip from Afghanistan, Iraq, or Syria to Germany or other parts of Western and Central Europe are positively selected in terms of their socio-economic status compared to those who stay at origin or who remain in Middle Eastern countries such as Jordan or Turkey. Overcoming long geographic distances implies a relatively high amount of financial resources (González-Ferrer et al. 2014) as well as knowledge about migration routes, means of transportation, smugglers, and more. Therefore, less well-off refugees are less likely to arrive in Germany, unlike those with a certain level of education and financial means. This might explain why our data does not show significant effects for the financial resources of couples on their migration strategy, as couples with at least one partner in Germany are relatively homogenous regarding their economic conditions. Fourth, the existence of family members at destination, and particularly those residing in the same household or locality, is crucial for the solo migration of one partner, which holds true for both women and men. Although the data did not allow for a detailed examination of the exact timing and sequencing of the migration events of couples in relation to those of their extended family - thus no 'classic' network effects could be traced the results showed that spouses' migration practices are linked to the migration dynamics of other relatives. Fifth, our study shows that male first-movers have a higher probability of reunifying with their wives within the first year after their arrival if they have a 'secure' residence permit, assuming that they tend to use legal family reunification channels. In contrast, female first-movers are followed relatively quickly by their partners, apparently not necessarily relying on procedural family reunification channels.

Although this study provides valuable insights into the partnership arrangements and practices of recently arrived refugees, several limitations must be acknowledged. Despite the unique information on family migration patterns covered by the IAB-BAMF-SOEP survey, most of the limitations are data-related. First, only few questions on past events were asked and several aspects on the timing of some measures are missing. For example, we do not know since when other family members have been living in Germany and whether they arrived together with or before/after the respondent. Furthermore, the data do not provide information on when the respondent obtained their current legal status, nor can people with subsidiary protection status be identified clearly. Moreover, details on the exact order of events over a couple's family and flight trajectory could be used for eventhistory analyses, which would allow for a more detailed examination of the exact timing and pace of reunification of both partners. Second, the analysis would improve if we could include information on both partners or at the household level into the same model. However, the dataset only provides individual information (such as age, education, income) for the respondent and their cohabiting spouse when they were also interviewed. Yet for partners residing elsewhere in Germany or abroad this information is missing. Third, although we control for the country of origin in the first step of the analyses, we could not perform more detailed analyses for each of these countries due to small case numbers, especially for female respondents. Furthermore, the sample sizes for the other countries of origin contained in the dataset were too small to include them into the analyses. For instance, although migration flows from Eritrea to Germany are also dominated by asylum seekers, diverging patterns regarding their spousal migration practices may ap- 
pear, since the predominant reasons for flight and the prevailing migration regime are different from those of refugees from Afghanistan, Iraq, or Syria.

Notwithstanding these limitations, the current study provides new perspectives and innovative theoretical and empirical insights to existing research on family migration processes of refugees. This is especially important as our findings show that previous research and hypotheses for mainly economically driven migration are not necessarily transferable to the context of forced migration. Moreover, our research demonstrates that migration is a highly gendered process, and that this also holds true for the family migration processes of refugees. Future research could apply the hypotheses presented in this study to other destinations of forced migrants in order to deepen our understanding of family migration processes of refugees. Investigating the effect that receiving contexts with different legal conditions and diverging struggles and possibilities for the successful integration of refugees may have on families' migration process is a relevant issue for further research.

\section{Acknowledgements}

This study received useful suggestions at its initial stage from the participants of the workshop "Family Migration Processes in a Comparative Perspective: Causes, Patterns, Effects", for which we are very thankful. We are also very grateful for the valuable and constructive comments and support provided by the editors of this special collection and by two anonymous reviewers.

\section{References}

Bähr, S., Beste, J. \& Wenzig, C. (2019). Arbeitsmarktintegration von geflüchteten Syrern und Irakern im $S G B$ II. Gute Sprachkenntnisse sind der wichtigste Erfolgsfaktor. Nürnberg: Institut für Arbeitsmarkt- und Berufsforschung (IAB-Kurzbericht 5/2019).

Bakker, L., Engbersen, G. \& Dagevos, J. (2014). In exile and in touch. Transnational activities of refugees in a comparative perspective. Comparative Migration Studies, 2, 3, pp. 261-282. doi: 10.5117/CMS2014.3.BAKK.

Baldassar, L. (2016). Mobilities and communication technologies: Transforming care in family life. In: Kilkey, M. \& Palenga-Möllenbeck, E. (Eds.), Mobilities and Communication Technologies: Transforming care in family life. London: Palgrave Macmillan, pp. 19-42.

Baldassar, L. \& Merla, L. (2014). Transnational families, migration and the circulation of care. Understanding mobility and absence in family life. New York: Routledge.

BAMF (2018). Das Bundesamt in Zahlen 2017. Asyl, Migration und Integration. Nürnberg: Bundesamt für Migration und Flüchtlinge.

BAMF (2019a). Antrags-, Entscheidungs- und Bestandsstatistik 2018. Nürnberg: Bundesamt für Migration und Flüchtlinge.

BAMF (2019b). Das Bundesamt in Zahlen 2018. Asyl. Nürnberg: Bundesamt für Migration und Flüchtlinge.

Barthel, F. \& Neumayer, E. (2015). Spatial dependence in asylum migration. Journal of Ethnic and Migration Studies, 41, 7, pp. 1131-1151. doi: 10.1080/1369183X.2014.967756.

Beauchemin, C., Nappa, J., Schoumaker, B., Baizan, P., González-Ferrer, A., Caarls, K. \& Mazzucato, V. (2015). Reunifying versus living apart together across borders. A comparative analysis of Sub- 
Saharan migration to Europe. International Migration Review, 49, 1, pp. 173-199. doi: 10.1111/imre.12155.

BMI \& BAMF (2019). Migrationsbericht der Bundesregierung. Migrationsbericht 2016/2017. Berlin: Bundesministerium des Innern/Nürnberg: Bundesamt für Migration und Flüchtlinge.

Brenzel, H., Brücker, H., Fendel, T., Guichard, L., Jaschke, P., Keita, S. et al. (2019). Flüchtlingsmonitoring: Endbericht. Nürnberg: Institut für Arbeitsmarkt- und Berufsforschung (Bundesministerium für Arbeit und Soziales. Forschungsbericht 528).

Brücker, H., Croisier, J., Kosyakova, Y., Kröger, H., Pietrantuono, G., Rother, N. \& Schupp, J. (2019). Zweite Welle der IAB-BAMF-SOEP-Befragung. Geflüchtete machen Fortschritte bei Sprache und Beschäftigung. Nürnberg: Institut für Arbeitsmarkt- und Berufsforschung (IAB-Kurzbericht 03/2019).

Brücker, H., Rother, N., Schupp, J., Babka von Gostomski, C., Böhm, A., Fendel, T. Friedrich, M., Giesselmann, M., Holst, E., Kosyakova, Y., Kroh, M., Liebau, E., Richter, D., Romiti, A., Schacht, D., Scheible, J. A., Schmelzer, P., Siegert, M., Sirries, S., Trübswetter, P., Vallizadeh, E. (2016). IABBAMF-SOEP-Befragung von Geflüchteten. Flucht, Ankunft in Deutschland und erste Schritte der Integration. Nürnberg: Institut für Arbeitsmarkt- und Berufsforschung (IAB-Kurzbericht 24/2016).

Bueno García, X. \& Vono de Vilhena, D. (2009). Pautas reproductivas de las madres latinoamericanas en Estados Unidos y España a inicios del siglo XXI. Aarhus: Aarhus Universitet.

Bürmann, M., Haan, P., Kroh, M. \& Troutman, K. (2018). Beschäftigung und Bildungsinvestitionen von Geflüchteten in Deutschland. Berlin: Deutsches Institut für Wirtschaftsforschung (DIW Wochenbericht, 42/2018).

Caarls, K., (2015). Living apart together across borders. How Ghanaian couples form, transform, or dissolve in the context of international migration. Maastricht: Maastricht University ( $\mathrm{PhD}$ Thesis).

Caarls, K. \& Mazzucato, V. (2015). Does international migration lead to divorce? Ghanaian couples in Ghana and abroad. Population, 70, 1, pp. 127-151. doi: 10.3917/popu.1501.0135.

Caarls, K. \& Mazzucato, V. (2016). Transnational relationships and reunification: Ghanaian couples between Ghana and Europe. Demographic Research, 34, 21, pp. 587-614. doi: 10.4054/DemRes.2016.34.21.

Caarls, K. \& Valk, H. de (2017). Relationship trajectories, living arrangements, and international migration among Ghanaians. Population, Space and Place, 23, 6. doi: 10.1002/psp.2046.

Caarls, K. C., Haagsman, K., Kraus, E. K. \& Mazzucato, V. (2018). African transnational families: Cross-country and gendered comparisons. Population, Space and Place, e2162. doi: $10.1002 /$ psp. 2162 .

Castles, S. (2007). The migration-asylum nexus and regional approaches. In: Kneebone, S. \& RawlingsSanaei, F. (Eds.), The migration-asylum nexus and regional approaches. London: Berghahn Books, pp. $25-42$.

Cerrutti, M. \& Gaudio, M. (2010). Gender differences between Mexican migration to the United States and Paraguayan migration to Argentina. The ANNALS of the American Academy of Political and Social Science, 630, 1, pp. 93-113. doi: 10.1177/0002716210368105.

Cerrutti, M. \& Massey, D. S. (2001). On the auspices of female migration from Mexico to the United States. Demography, 38, 2, pp. 187-200. doi: 10.1353/dem.2001.0013.

Collyer, M. \& Haas, H. de (2012). Developing dynamic categorisations of transit migration. Population, Space and Place, 18, 4, pp. 468-481.

Crawley, H., Düvell, F., Jones, K., McMahon, S. \& Sigona, N. (2016). Destination Europe? Understanding the dynamics and drivers of Mediterranean migration in 2015. MEDMIG Final Report.

Crawley, H. \& Skleparis, D. (2018). Refugees, migrants, neither, both: categorical fetishism and the politics of bounding in Europe's 'migration crisis'. Journal of Ethnic and Migration Studies, 44, 1, pp. 48-64. doi: 10.1080/1369183X.2017.1348224.

Curran, S. R. \& Rivero-Fuentes, E. (2003). Engendering migrant networks: The case of Mexican migration. Demography, 40, 2, pp. 289-307. doi: 10.2307/3180802.

Di Barbiano Belgiojoso, E. \& Terzera, L. (2018). Family reunification - who, when, and how? Family trajectories among migrants in Italy. Demographic Research, 38, pp. 737-772. doi: 10.4054/DemRes.2018.38.28. 
Dreby, J. (2010). Divided by borders: Mexican migrants and their children. Berkeley: University of California Press.

Fresnoza-Flot, A. (2018). Beyond migration patterns - Understanding family reunion decisions of Filipino labour and Thai marriage migrants in global reproductive systems. Migration Studies, 6, 2, pp. 205-224. doi: 10.1093/migration/mnx038.

Gambaro, L., Kreyenfeld, M., Schacht, D. \& Spieß, C. K. (2018). Lebenszufriedenheit von Geflüchteten in Deutschland ist deutlich geringer, wenn ihre Kinder im Ausland leben. Berlin: Deutsches Institut für Wirtschaftsforschung (DIW Wochenbericht 42/2018).

Geisen, T. (2014). Multilokale Existenzweisen von Familien im Kontext von Migration. Herausforderungen für Forschung und Theorieentwicklung. In: Geisen, T., Studer, T. \& Yildiz, E. (Eds.), Multilokale Existenzweisen von Familien im Kontext von Migration. Herausforderungen für Forschung und Theorieentwicklung. Wiesbaden: VS Verlag für Sozialwissenschaften, pp. 27-57.

Glick, J. E. (2010). Connecting complex processes: A decade of research on immigrant families. Journal of Marriage and Family, 72, 3, pp. 498-515. doi: 10.1111/j.1741-3737.2010.00715.x.

González-Ferrer, A. (2007). The process of family reunification among original guest-workers in Germany. Zeitschrift für Familienforschung, 19, 1, pp. 10-33.

González-Ferrer, A., Baizán, P., Beauchemin, C., Kraus, E., Schoumaker, B. \& Black, R. (2014). Distance, transnational arrangements, and return decisions of Senegalese, Ghanaian, and Congolese migrants. International Migration Review, 48, 4, pp. 939-971.

Grote, J. (2017). Familiennachzug von Drittstaatsangehörigen nach Deutschland. Fokusstudie der deutschen nationalen Kontaktstelle für das Europäische Migrationsnetzwerk (EMN). Nürnberg: Bundesamt für Migration und Flüchtlinge (Working Paper 73).

Gupta, P. (2003). Marriage at a distance: Spouse separation and the migrant family. Philadelphia: Population Studies Center.

Guveli, A., Ganzeboom, H. B. G., Platt, L., Nauck, B., Baykara-Krumme, H., Eroğlu, Ş. et al. (2016). Intergenerational consequences of migration. Socio-economic, family and cultural patterns of stability and change in Turkey and Europe. Basingstoke: Palgrave Macmillan.

Haagsman, K., (2015). Parenting across borders. Effects of transnational parenting on the lives of Angolan and Nigerian migrant parents in the Netherlands. Maastricht: Maastricht University (PhD Thesis).

Heering, L., van der Erf, R. \& van Wissen, L. (2004). The role of family networks and migration culture in the continuation of Moroccan emigration: A gender perspective. Journal of Ethnic and Migration Studies, 30, 2, pp. 323-337. doi: 10.1080/1369183042000200722.

Hessels, T. \& Wassie, F. (2003). Afghanen in Nederland. Een profiel. Den Haag: Ministerie van Binnenlandse Zaken en Koninkrijksrelaties.

Hondagneu-Sotelo, P. (1994). Gendered transitions: Mexican experiences of immigration. Berkeley: University of California Press.

Jacobsen, J., Klikar, J. \& Schupp, J. (2017). Scales manual IAB-BAMF-SOEP survey of refugees in Germany - revised version. Berlin: Deutsches Institut für Wirtschaftsforschung (SOEP Survey Papers 475).

Jastram, K. \& Newland, K. (2003). Family unit and refugee protection. In: Feller, E., Türk, V. \& Nicholson, F. (Eds.), Family unit and refugee protection. Cambridge: Cambridge University Press, pp. 556-603.

Kanaiaupuni, S. M. (2000). Reframing the migration question: An analysis of men, women, and gender in Mexico. Social Forces, 78, 4, pp. 1311-1347. doi: 10.2307/3006176.

Kofman, E. (2004). Family-related migration: A critial review of European Studies. Journal of Ethnic and Migration Studies, 30, 2, pp. 243-262. doi: 10.1080/1369183042000200687.

Kofman, E., Kraler, A., Kohli, M. \& Schmoll, C. (2011). Introduction issues and debates on familyrelated migration and the migrant family: A European perspective. In: Kofman, E., Kraler, A., Kohli, M. \& Schmoll, C. (Eds.), Gender, Generations and the Family in International Migration, pp. 13-54. 
Koser, K. \& Martin, S. (2011). The migration-displacement nexus: Patterns, processes and policies. Oxford: Berghahn Books.

Koser, K. \& Pinkerton, C. (2002). The social networks of asylum seekers and the dissemination of information about countries of asylum. London: Research, Development and Statistics Directorate.

Kraus, E. K. (2019). Family formation trajectories across borders: A sequence analysis approach to Senegalese migrants in Europe. Advances in Life Course Research, 42, 100290. doi: 10.1016/j.alcr.2019.100290.

Kroh, M., Brücker, H., Kühne, S., Liebau, E., Schupp, J., Siegert, M. et al. (2016). Das Studiendesign der IAB-BAMF-SOEP Befragung von Geflüchteten. Berlin: Deutsches Institut für Wirtschaftsforschung (SOEP Survey Papers 365).

Kroh, M., Kühne, S., Jacobsen, J., Siegert, M., Siegers, R. (2018). Sampling, nonresponse, and integrated weighting of the 2016 IAB-BAMF-SOEP Survey of Refugees (M3/M4) - revised version. Berlin: Deutsches Institut für Wirtschaftsforschung (SOEP Survey Papers 477).

Long, K. (2013). When refugees stopped being migrants: Movement, labour and humanitarian protection. Migration Studies, 1, 1, pp. 4-26.

Lutz, H. (2004). Transnationale Biographien in globalisierten Gesellschaften. In: Ottersbach, M. \& Yildiz, E. (Eds.), Migration in der metropolitanen Gesellschaft. Zwischen Ethnisierung und globaler Neuorientierung. Münster: LIT Verlag, pp. 207-216.

Martin, S. F. (2009). Introduction. In: Martin, S. F. \& Tirman, J. (Eds.), Women, migration and conflict: Breaking a deadly cycle. Dordrecht, Heidelberg, London, New York: Springer Science+Business Media, pp. 1-22.

Massey, D. S. (1990). Social structure, household strategies, and the cumulative causation of migration. Population Index, 56, 1, pp. 3-26. doi: 10.2307/3644186.

Massey, D. S., Alarcón, R., Durand, J. \& González, H. (1987). Return to Aztlan: The social process of international migration from Western Mexico. Berkeley: University of California Press.

Massey, D. S. \& Espinosa, K. (1997). What's driving Mexico-U.S. migration? A theoretical, empirical and policy analysis. American Journal of Sociology, 102, 4, pp. 939-999. doi: 10.1086/231037.

Massey, D. S., Fischer, M. J. \& Capoferro, C. (2006). International migration and gender in Latin America. A comparative analysis. International Migration, 44, 5, pp. 63-91. doi: $10.1111 / \mathrm{j} .1468-2435.2006 .00387 . x$.

Morris, L. (2002). Managing migration: Civic stratification and migrants' rights. London, New York: Routledge.

Neumayer, E. (2005). Bogus refugees? The determinants of asylum migration to Western Europe. International Studies Quarterly, 49, 4, 389-409. doi: 10.1111/j.1468-2478.2005.00370.x.

OECD (2017). Nach der Flucht: Der Weg in die Arbeit - Arbeitsmarktintegration von Flüchtlingen in Deutschland. Paris: OECD.

Palloni, A., Massey, D. S., Ceballos, M., Espinosa, K. \& Spittel, M. (2001). Social capital and international migration: A test using information on family networks. American Journal of Sociology, 106, 5, pp. 1262-1298. doi: 10.1086/320817.

Parreñas, R. S. (2005). Long distance intimacy: Class, gender and intergenerational relations between mothers and children in Filipino transnational families. Global Networks - A Journal of Transnational Affairs, 5, 4, pp. 317-336. doi: 10.1111/j.1471-0374.2005.00122.x.

Pessar, P. (1999). The role of gender, households, and social networks in the migration process: A review and appraisal. In: Hirschman, C., Kasinitz, P. \& DeWind Joshua (Eds.), The handbook of international migration. New York: Russell Sage Foundation, pp. 53-70.

Richmond, A. H. (1993). Reactive migration: Sociological perspectives on refugee movements. Journal of Refugee Studies, 6, 1, pp. 7-24.

Robertson, Z., Wilding, R. \& Gifford, S. (2016). Mediating the family imaginary: Young people negotiating absence in transnational refugee families. Global Networks, 16, 2, 219-236.

Ryan, L., Sales, R., Tilki, M. \& Siara, B. (2009). Family strategies and transnational migration: Recent Polish migrants in London. Journal of Ethnic and Migration Studies, 35, 1, pp. 61-77. doi: $10.1080 / 13691830802489176$. 
Sample, E. (2007). State practice and the family unity of African refugees. Forced Migration Review, 28, pp. 50-52.

Sauer, L., Diabaté, S., Gabel, S., Halfar, Y., Kraus, E. K. \& Wenzel, L. (2018). Doing transnational family im Kontext von Flucht und Krisenmigration: Stand der Forschung. Wiesbaden: Bundesinstitut für Bevölkerungsforschung.

Schmalzbauer, L. (2010). Disruptions, dislocations, and inequalities: Transnational Latino/a families surviving the global economy. North Carolina Law Review, 88, 5, pp. 1857-1880.

Schouler-Ocak, M. \& Kurmeyer, C. (2017). Study on female refugees. Repräsentative Untersuchung von geflüchteten Frauen in unterschiedlichen Bundesländern in Deutschland. Berlin: Charité.

Söhn, J. (2013). Unequal welcome and unequal life chances: How the state shapes integration opportunities of immigrants. European Journal of Sociology, 54, 2, pp. 295-326. doi: 10.1017/S0003975613000155.

Staver, A. (2008). Family reunification. A right for forced migrants? Oxford: Refugee Studies Centre.

Stoewe, K. (2018). Education levels of refugees: Training and education in the main countries of origin. Understanding refugees' educational backgrounds. Köln: Institut der deutschen Wirtschaft.

Toma, S. \& Vause, S. (2013). On their own? A study of independent versus partner-related migration from the Democratic Republic of the Congo and Senegal. Journal of Intercultural Studies, 34, 5, pp. 533-552. doi: 10.1080/07256868.2013.827832.

Toma, S. \& Vause, S. (2014). Gender differences in the role of migrant networks. Comparing Congolese and Senegalese migration flows. International Migration Review, 48, 4, pp. 972-997. doi: 10.1111/imre.12150.

UNHCR (2013). A New Beginning. Refugee Integration in Europe. Outcome of an EU funded project on Refugee Integration Capacity and Evaluation (RICE). Geneva: UNHCR.

UNHCR (2019). Global trends. Forced displacement in 2018. Geneva: UNHCR.

van Hear, N. (2014). Reconsidering migration and class. International Migration Review, 48, pp. 100121. doi: 10.1111 /imre. 12139.

van Houte, M. (2016). Migration, diasporas and citizenship. Return migration to Afghanistan. Moving back or moving forward? Oxford: Palgrave Macmillan.

Vives, L. \& Vazquez Silva, I. (2017). Senegalese migration to Spain: Transnational mothering practices. Journal of Ethnic and Migration Studies, 43, 3, pp. 495-512. doi: 10.1080/1369183X.2016.1186531.

Wilmsen, B. (2011). Family separation. The policies, procedures, and consequences for refugee background families. Refugee Survey Quarterly, 30, 1, pp. 44-64. doi: 10.1093/rsq/hdq045.

Winters, P., Janvry, A. de \& Sadoulet, E. (2001). Family and community networks in Mexico-U.S. migration. The Journal of Human Resources, 36, 1, pp. 159-184. doi: 10.2307/3069674.

Witteborn, S. (2015). Becoming (im)perceptible: Forced migrants and virtual practice. Journal of Refugee Studies, 28, 3, pp. 350-367. doi: 10.1093/jrs/feu036.

Zetter, R. (2007). More labels, fewer refugees: Remaking the refugee label in an era of globalization. Journal of Refugee Studies, 20, 2, pp. 172-192.

Zetter, R. (2015). Protection in crisis: Forced migration in a global era. Washington: Migration Policy Institute.

Submitted: May, 2, 2019

Accepted: October, 19, 2019 
Addresses of the authors:

Elisabeth K. Kraus (corresponding author)

Lenore Sauer

Federal Institute for Population Research

Friedrich-Ebert-Allee 4

65185 Wiesbaden

Germany

Email: elisabeth.kraus@bib.bund.de lenore.sauer@bib.bund.de

Laura Wenzel

Leuphana University of Luneburg,

Department of Social Pedagogy and Social Work

Universitätsallee 1

21335 Lüneburg

Germany

Email: laura.wenzel@leuphana.de 


\section{Appendix}

Table A1: Descriptive statistics of independent variables by sex; reunified versus not reunified within one year of arrival of first-mover (step 2)

\begin{tabular}{|c|c|c|c|c|c|c|c|c|c|c|c|c|c|}
\hline & \multicolumn{6}{|c|}{ Women } & \multicolumn{6}{|c|}{ Men } \\
\hline & & \multicolumn{2}{|c|}{ Reunified } & \multicolumn{2}{|c|}{$\begin{array}{c}\text { Not } \\
\text { Reunified }\end{array}$} & \multicolumn{2}{|c|}{ Total } & \multicolumn{2}{|c|}{ Reunified } & \multicolumn{2}{|c|}{$\begin{array}{c}\text { Not } \\
\text { Reunified }\end{array}$} & \multicolumn{2}{|c|}{ Total } \\
\hline & & $\mathrm{N}$ & $\%$ & $\mathrm{~N}$ & $\%$ & $\mathrm{~N}$ & $\%$ & $\mathrm{~N}$ & $\%$ & $\mathrm{~N}$ & $\%$ & $\mathrm{~N}$ & $\%$ \\
\hline \multirow{3}{*}{$\begin{array}{l}\text { Age at arrival } \\
\text { (mean years) } \\
\text { Arrival period }\end{array}$} & & \multicolumn{2}{|c|}{32.9} & \multicolumn{2}{|c|}{36.6} & \multicolumn{2}{|c|}{35.7} & \multicolumn{2}{|c|}{34.2} & \multicolumn{2}{|c|}{32.5} & \multicolumn{2}{|c|}{32.8} \\
\hline & before 2015 & 10 & 16.8 & 15 & 9.3 & 25 & 11.1 & 31 & 23.3 & 50 & 15.2 & 81 & 16.4 \\
\hline & 2015 and after & 22 & 83.2 & 62 & 90.7 & 84 & 88.9 & 91 & 76.7 & 169 & 84.8 & 260 & 83.6 \\
\hline \multirow[t]{4}{*}{ Schooling (years) } & $0-6$ & 8 & 35.0 & 25 & 26.1 & 33 & 28.2 & 29 & 27.5 & 41 & 16.8 & 70 & 18.4 \\
\hline & $7-11$ & 11 & 36.2 & 16 & 18.9 & 27 & 23.0 & 24 & 16.5 & 65 & 30.8 & 89 & 28.7 \\
\hline & $12+$ & 11 & 24.2 & 30 & 35.2 & 41 & 32.6 & 60 & 46.7 & 100 & 46.7 & 160 & 46.7 \\
\hline & missing & 2 & 4.7 & 6 & 19.8 & 8 & 16.2 & 9 & 9.3 & 13 & 5.7 & 22 & 6.2 \\
\hline \multirow[t]{3}{*}{ Migration reasons } & only flight reasons & 16 & 58.2 & 36 & 43.6 & 52 & 47.1 & 74 & 44.1 & 98 & 47.1 & 146 & 46.7 \\
\hline & also other reasons & 16 & 41.8 & 41 & 56.4 & 57 & 53.0 & 48 & 55.9 & 119 & 51.1 & 193 & 51.8 \\
\hline & missing & 0 & 0.0 & 0 & 0.0 & 0 & 0.0 & 0 & 0.0 & 2 & 1.8 & 2 & 1.6 \\
\hline \multirow[t]{6}{*}{ Net income before flight } & ever worked & 10 & 20.5 & 34 & 49.0 & 44 & 42.2 & & & & & & \\
\hline & not/never worked & 22 & 79.5 & 37 & 43.5 & 59 & 52.0 & 4 & 2.4 & 11 & 6.3 & 15 & 5.8 \\
\hline & below average & & & & & & & 29 & 22.8 & 63 & 29.9 & 92 & 28.8 \\
\hline & average & & & & & & & 49 & 47.3 & 84 & 39.8 & 133 & 41.0 \\
\hline & above average & & & & & & & 37 & 26.2 & 49 & 16.9 & 86 & 18.3 \\
\hline & missing & 0 & 0.0 & 6 & 7.6 & 6 & 5.8 & 3 & 1.3 & 12 & 7.1 & 15 & 6.2 \\
\hline \multirow[t]{4}{*}{ Children } & no children $<18$ & 3 & 5.4 & 14 & 16.5 & 17 & 13.9 & 29 & 24.7 & 64 & 36.3 & 93 & 34.5 \\
\hline & $1-2$ children $<18$ & 8 & 45.3 & 33 & 49.0 & 41 & 48.1 & 40 & 45.0 & 78 & 33.9 & 118 & 35.5 \\
\hline & $3+$ children $<18$ & 21 & 49.4 & 30 & 34.5 & 52 & 38.0 & 53 & 30.3 & 74 & 28.5 & 127 & 28.8 \\
\hline & missing & 0 & 0.0 & 0 & 0.0 & 0 & 0.0 & 0 & 0.0 & 3 & 1.3 & 3 & 1.1 \\
\hline \multirow{3}{*}{$\begin{array}{l}\text { Family members in } \\
\text { same locality }\end{array}$} & no & 25 & 82.4 & 52 & 71.5 & 77 & 74.1 & 90 & 76.3 & 179 & 87.8 & 269 & 86.1 \\
\hline & yes & 7 & 17.6 & 25 & 28.5 & 32 & 25.9 & 32 & 23.8 & 40 & 12.2 & 72 & 13.9 \\
\hline & missing & 0 & 0.0 & 0 & 0.0 & 0 & 0.0 & 0 & 0.0 & 0 & 0.0 & 0 & 0.0 \\
\hline \multirow[t]{4}{*}{ Legal status } & secure status & 21 & 39.0 & 49 & 30.9 & 38 & 32.9 & 104 & 85.5 & 147 & 41.6 & 87 & 37.4 \\
\hline & other status & 10 & 59.8 & 28 & 69.1 & 70 & 66.9 & 15 & 13.5 & 72 & 58.4 & 251 & 62.5 \\
\hline & missing & 1 & 1.2 & 0 & 0.0 & 1 & 0.3 & 3 & 1.0 & 0 & 0.0 & 3 & 0.2 \\
\hline & Total & 32 & 23.8 & 77 & 76.2 & 109 & 100.0 & 122 & 15.2 & 219 & 84.8 & 341 & 100.0 \\
\hline
\end{tabular}

Data: IAB-BAMF-SOEP, waves 1 \& 2, 2016-2017 (unweighted N, weighted percentages); due to rounding percentages may not total $100 \%$. 
Figure A1: Kaplan-Meier survival estimates of reunification with left-behind partner by sex of first-mover

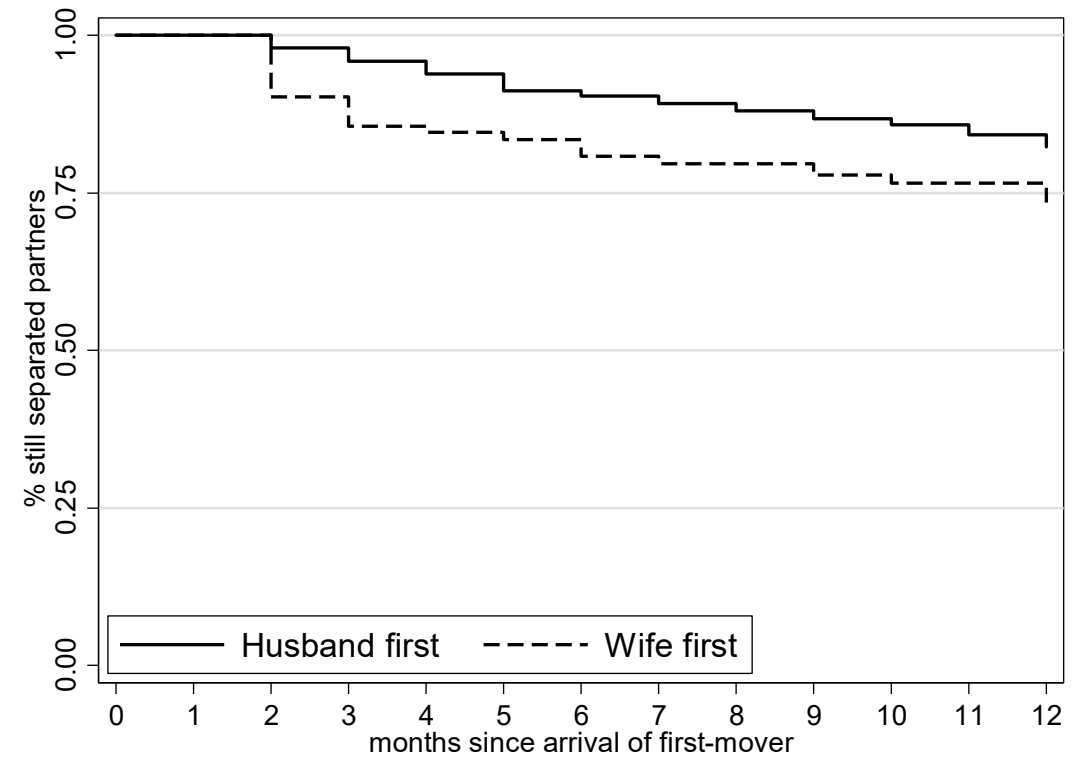

Data: IAB-BAMF-SOEP, waves 1 \& 2, 2016-2017 (weighted). 